\title{
Birthday Buddies
}

\author{
Charles W. Shafer, MD
}

(Fam Med. 2020;52(1):65-6.)

doi: 10.22454/FamMed.2020.552586

I t was my daughter's fifth birthday. No, not just any daughter, but the caboose daughter who followed by 10 years a train of five sons. So in my hurried preparations to leave for an early morning delivery, I paused long enough to delicately kiss her forehead, knowing I wouldn't see her again until evening. Zoe adores babies and would have been excited to know I was headed to labor and delivery. On a previous call night when I told her I was going to help a baby be born, she asked sincerely, "Could you bring it home so I could see it?"

The delivery itself went quite well; in fact, it was an impressive performance by a 20 year-old first-time mom. Dilated to seven centimeters on arrival at the hospital, she quickly progressed to complete cervical dilation. Though she pushed for 2 full hours, she did so without benefit of any pain medication and maintained generally admirable composure throughout. The first-year resident, still clinging to the steep portion of the obstetrical learning curve, handled the delivery well, with an assist from me on the clamp and cut of a tight nuchal cord. She proudly presented the healthy baby girl to her joyful parents. A somewhat unusual vaginal laceration was no match for our collaborative repair efforts.

With a morning scheduled full with meetings, I had but one patient to see before lunch. Toni was coming in for a hospital follow-up after having been diagnosed with widely metastatic, non-small cell lung cancer a few days earlier at age forty-six. Not surprisingly, there were tears. There had been tears the first time we met as well. On that day Toni had been sixteen, pregnant, and scared as we sat together with her mother in an exam room during my second year of family medicine residency. It was the beginning of the kind of relationship that is unique to family doctors and their patients. The pregnancy itself was fairly unremarkable and Toni ended up making the difficult decision to give her baby boy a more stable home environment by adopting out. As one might anticipate, our relationship deepened, though neither of us could have predicted it would continue for more than 3 decades, culminating in her terminal diagnosis.

I cared for Toni through the births of three more children, a couple of marriages, and the usual vicissitudes of life, with a few curveballs thrown in. Her dysplastic nevus syndrome led to numerous excisional biopsies over the years, one of which, unfortunately was found to be a malignant melanoma. After surgical excision, this was considered to have been cured and we breathed a cautious sigh of relief. She also suffered from degenerative disc disease of the lumbar spine, resulting in chronic back and leg pain. Toni's chronic pain had developed at a time when the pendulum was swinging toward long-term opiate therapy for nonmalignant pain. That, in combination with her being uninsured, led to her being treated with methadone to keep her pain controlled well enough to enable her to continue to work. Despite my persistent efforts, I was never able to get Toni to leave behind the smoking habit she acquired in her early teens.

As is frequently the case in family medicine, the process of caring for Toni and her children resulted in my acquiring her parents as patients as well. In this role I assisted her father through his recovery from multiple injuries resulting from a work-related accident, in addition to the management of several chronic medical conditions. Her mother Viola, who had been the emotional anchor of the family during the early years of my relationship with Toni, provided a great deal of support during the challenges of her somewhat tumultuous coming-of-age years. This fact probably contributed to the magnitude of the gut-punch we all felt when I diagnosed Viola with a leiomyosarcoma, a rare, yet deadly form of uterine cancer. I am certain she agonized over her approaching inability to provide care and support for her family, and despite numerous conversations, Viola held doggedly to her denial until her dying breath at age 45 .

From the Sioux Falls Family Medicine Residency, Department of Family Medicine, University of South Dakota Sanford School of Medicine, Sioux Falls, SD. 
These random recollections from our many years and experiences together now came back to me as I sat in the exam room with Toni and her husband Ron, discussing what they could expect in the coming weeks. We were able to come up with a plan to provide at least a measure of relief from the unremitting pain emanating from her extensive skeletal metastatic disease. With the advantage of having dealt with my wife's non-Hodgkin lymphoma diagnosis and subsequent successful chemotherapy and radiation years before, I was able to provide them with firsthand knowledge of the rollercoaster ride that cancer and its treatments afford. This experience also enabled me to provide genuine empathy to Ron and Toni as they faced this challenge that eclipsed all else in their lives. Though she fully understood the terminal nature of her disease, Toni's desire was to be present as long as possible for her family, especially her 11 and 13 year-old sons. In this spirit she underwent a single cycle of palliative chemotherapy, to which her body responded with multiorgan system failure. Though she recovered from this near-fatal episode and was willing to try again, Toni's precarious clinical status precluded a second cycle of chemotherapy. Sadly, after several more hospital admissions and evident clinical deterioration related to brain metastases, Toni was admitted to acute hospice where she passed away in the presence of her family just 10 weeks after being diagnosed.

But as I was visiting with Toni during her clinic visit that day, I was surprised to see that it was her birthday. After Toni and Ron left the clinic, I reflected on my day: a first birthday, a last birthday and the birthday of my own precious daughter, all rolled into 24 hours. The celebration and appreciation of my family had been amplified by the occasion to walk with my patients through the doors of life and death. And I marveled at the profoundness of our profession.

ACKNOWLEDGMENT: All patient names have been changed to preserve anonymity.

CORRESPONDENCE: Address correspondence to Dr Charles W. Shafer, Center for Family Medicine, 1115 East 20th Street, Sioux Falls, SD 57105. 605-575-1643. Fax: 605-335-1006. Charles.Shafer@c4fm.org. 